\title{
Site-Response Maps for the Los Angeles Region Based on Earthquake Ground Motions
}

By Stephen Hartzell

Stephen Harmsen

Arthur Frankel

David Carver

Edward Cranswick

Mark Meremonte

and

John Michael

Open-File Report 96-723

This report is preliminary and has not been reviewed for conformity with U.S. Geological Survey editorial standards. Any use of trade, product, or firm names is for descriptive purposes only and does not imply endorsement by the U.S. Government

Denver,. Colorado 80225-0046 


\title{
Site-Response Maps for the Los Angeles Region Based on Earthquake Ground Motions
}

\author{
BY Stephen Hartzell, Stephen Harmsen, Arthur Frankel, David Carver, \\ Edward Cranswick, Mark Meremonte, and John Michael
}

\begin{abstract}
Ground-motion records from aftershocks of the 1994 Northridge earthquake and main-shock records from the 1971 San Fernando, 1987 Whittier Narrows, 1991 Sierra Madre, and 1994 Northridge earthquakes are used to estimate site response in the urban Los Angeles, California, area. Two frequency bands are considered, 0.5-1.5 Hz and 2.0-6.0 $\mathrm{Hz}$. Instrument characteristics prevented going to lower frequencies, and frequencies above $6.0 \mathrm{~Hz}$ are less important to the building inventory. Site response determined at the instrumented locations is associated with the surficial geology and contoured to produce a continuous spatial estimation of site response. The maps in this report are preliminary and will evolve as more data become available and more analysis is done.
\end{abstract}

\section{INTRODUCTION}

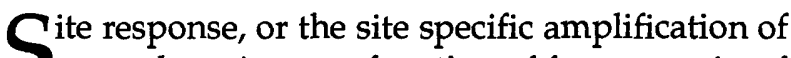
ground motion as a function of frequency, is a fundamental component of earthquake hazard assessment. Site response is also a desired component of any regional seismic hazard map. Previous site response studies in Los Angeles include Campbell (1976), who showed that damage during the 1933 Long Beach earthquake was greater for sites on unconsolidated soils than at sites on consolidated soils, for a given distance from the NewportInglewood fault zone. Rogers and others (1979) calculated site response in Long Beach using spectral ratios of Nevada Test Site (NTS) nuclear events. They found amplification factors as high as $\mathbf{1 1}$ in the frequency band from 0.16 to $5.0 \mathrm{~Hz}$ for alluvium-to-rock ratios. This work was continued by Rogers and others $(1980,1984,1985)$ to include additional sites in the Los Angeles area. They confirmed that low strain records from NTS nuclear events gave similar site response estimates as strongmotion records from the 1971 San Fernando earthquake. Their results show elevated site response at frequencies greater than $2.0 \mathrm{~Hz}$ with increased mean void ratio in the near-surface layers, unconsolidated sediment thickness, and depth to basement rock. At frequencies less than 2.0 $\mathrm{Hz}$, the most significant factors were reported to be thickness of Quaternary sediments and the depth to basement. The 1994 Northridge earthquake greatly increased the available ground-motion data for the urban Los Angeles area from which site-response estimates can be made. Recordings of this earthquake and its aftershocks have also greatly increased our understanding of the variabili- ty in site response over widely different length scales; from one city block to across entire sedimentary basins. In addition, instrument deployment for the Northridge earthquake targeted several specific areas of severe damage and compared them with low or nondamaged areas. This expanded data set has led to the feasibility of creating site-response maps for the Los Angeles area.

\section{DATA}

$T$ The data for this study are recorded earthquake ground motions. We use both aftershock and main-shock records to increase the size of our database. Deployment of portable digital recorders after the 1994 Northridge earthquake yielded an extensive collection of aftershock records for a wide variety of surficial geologic units (Meremonte, 1996; Glassmoyer, 1996). Figure 1 shows the distribution of portable recorders and table 1 gives their locations. Over 1,300 records from 61 sources and 87 sites are utilized. The main-shock records are SMA-1 strong motion accelerograms for the four events: 1971 San Fernando (M6.6), 1987 Whittier Narrows (M5.8), 1991 Sierra Madre (M5.8), and 1994 Northridge (M6.7). These records are available for 223 sites and give coverage to the south and west not represented in the Northridge aftershock data set. These records come from four primary sources: U.S. Geological Survey, California Strong Motion Instrumentation Program, University of Southern California, and Los Angeles Department of Water and Power (Porcella and others, 1994; Shakal and others, 1994, 1995; Trifunac and others, 1994). The main-shock station locations are shown on figure 2 and listed in table 2. 


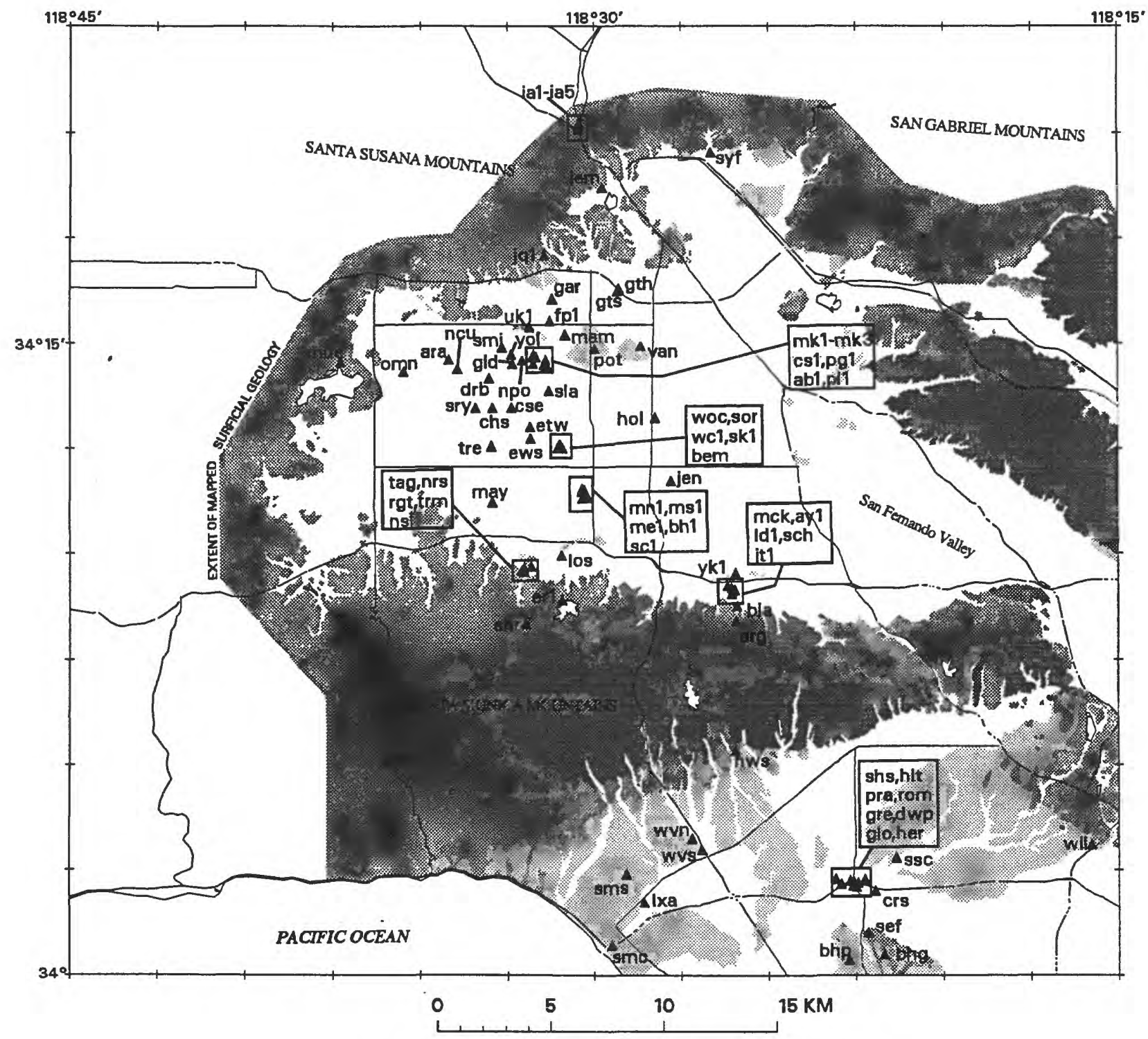

DESCRIPTION OF SURFICIAL GEOLOGIC UNITS

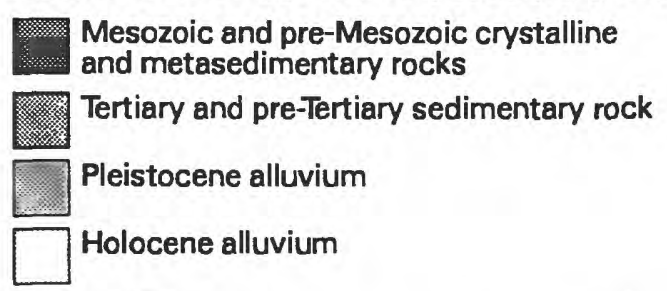

FIGURE 1. Aftershock station locations, indicated by triangles and listed in table 1, used in the determination of site response. Surficial geology is from Tinsley and Fumal (1985). 


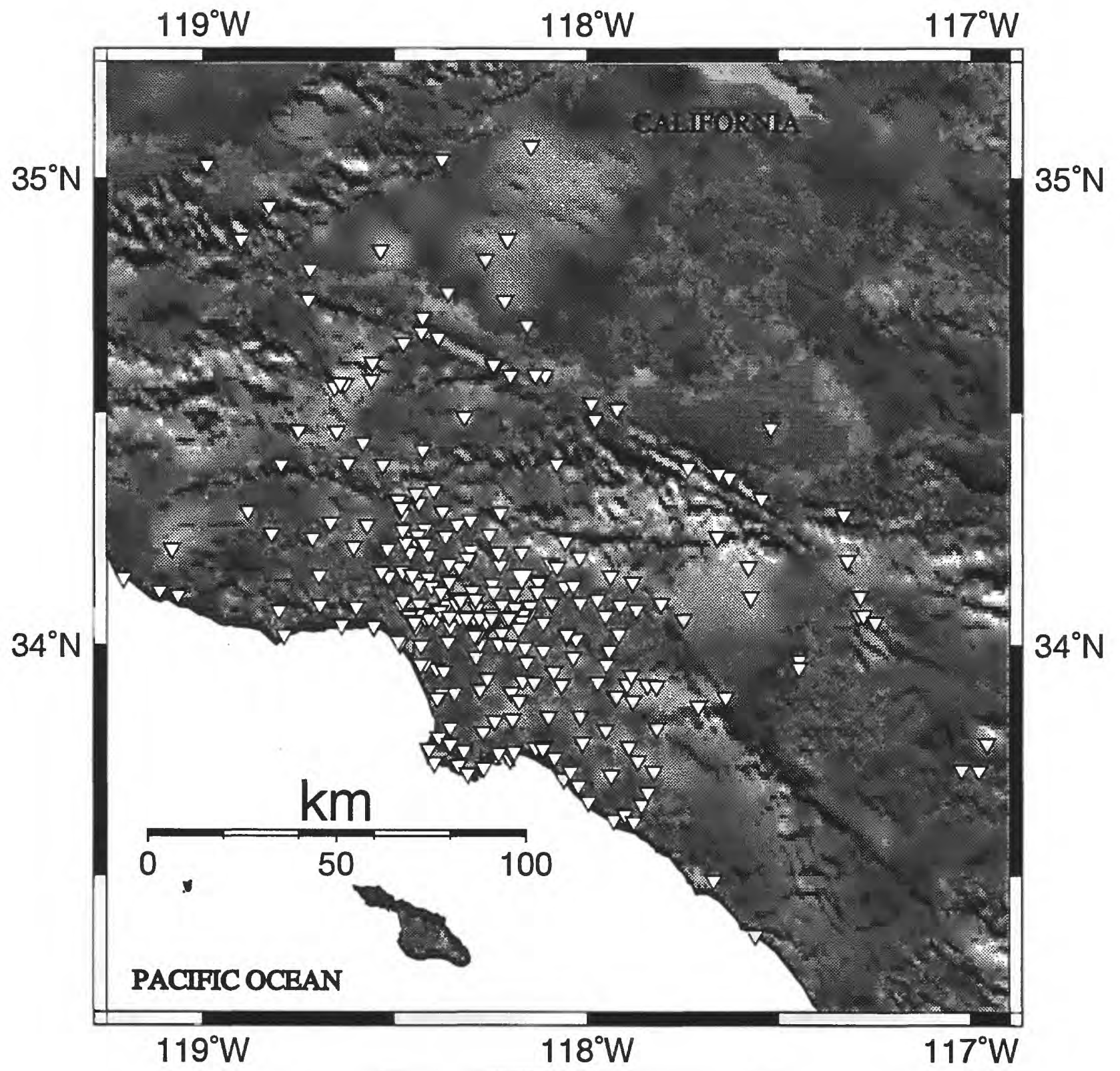

FIGURE 2. Strong-motion station locations, indicated by triangles and listed in table 2 , used in the determination of site response. 


\section{METHOD}

$\mathrm{T}_{\mathrm{in}}$ he method used to calculate site response is described in detail in two papers: Hartzell and others (1996) for the aftershock records, and Harmsen (1996) for the mainshock records. These two data sets present their own individual processing problems that are handled separately and described in the above papers. The general process, however, is relatively simple and is summarized here. The $S$ waves from the above data records are first transformed to the frequency domain using a fast Fourier transform. Then, following Andrews (1986), the S-wave spectrum, $U(f)$, for source $i$ and site $j$ is decomposed as

$$
S_{i}(f) \cdot R_{j}(f) \cdot P_{i j}(f, r)=U_{i j}(f),
$$

were $S(f)$ is the source spectrum, $R(f)$ is the site spectrum, $P(f)$ is the path spectrum, $f$ is frequency, and $r$ is the source to station distance. General assumptions are made about the nature of $\mathrm{P}(\mathrm{f}, \mathrm{r})$, including $1 / \mathrm{r}$ attenuation with distance and an elastic attenuation, $Q(f)$. Incorporating these propagation path effects and taking the logarithm of both sides gives the linear expression

$$
\log S_{i}\left(f_{k}\right)+\log R_{j}\left(f_{k}\right)=\log U_{i j}^{\prime}\left(f_{k}\right) \text {, }
$$

where $U^{\prime}(f)$ is the path-corrected $S$-wave spectrum. Linear least squares analysis can then be used to solve for the best-fitting source and site terms. Averages are then taken over frequency bands of $R(f)$ for each site to obtain the site amplification factors. Two frequency bands are selected, $0.5-1.5 \mathrm{~Hz}$ and $2.0-6.0 \mathrm{~Hz}$, on the basis of the bandwidth of the available ground-motion data. Main-shock records with suspected nonlinear effects have been omitted from the analysis.

The aftershock and strong-motion data results must be normalized with respect to each other. In the above analysis, a reference site is selected to remove a fundamental degree of freedom in the problem. The site response at this reference site must be specified. To accomplish the normalization, we select a common reference site for both the aftershock and main-shock record analysis. We choose one of the most competent rock sites in our database and assume its amplification is approximately 1 at all frequencies. This site is the Encino Reservoir Dam, ER1 in the aftershock data set (table 1) and ERD in the mainshock data set (table 2). These two stations are separated by approximately $20 \mathrm{ft}$.

\section{SPATIAL CONTINUATION OF SITE RESPONSE}

iven the point determinations of site response at each
of the recording sites, a method is needed to spatially
continue these values to produce a map. Surficial geology
and shallow S-wave velocity are logical means of interpo-
lating and extrapolating our point values of site response.
The correlation of larger ground motion with less competent surficial material and lower $S$-wave velocity has long been observed and used in studies of site response (Borcherdt, 1970, 1994; Boore and others, 1993, 1994; Joyner and Fumal, 1984; and Harmsen, 1996). In the work of Hartzell and others (1996) and Harmsen (1996), however, significant variations in site response are observed for the same mapped surficial geologic unit, particularly within the young basin sediments (factor of 2 in amplitude within a few hundred meters). These results reflect the fact that shallow $S$-wave velocities vary significantly within these sediments (Williams and others, 1996; Harmsen, 1996) and buried structures such as folds and mini-basins focus and defocus energy at the surface. Because of these variations in $S$-wave velocity and the sparseness of the $S$-wave data set, $S$-wave velocity is presently not a feasible means of spatially continuing our site amplification values. For this report we have chosen a compromise by calculating average site amplification values for Mesozoic and Tertiary rocks and Pleistocene and Holocene alluvium, as well as contouring the amplification values within the more spatially variable sedimentary basins. With minor corrections to the extent of the hard-rock units, we use the surficial geology of Tinsley and Fumal (1985).

Table 3 lists the average amplification values for the four ages (Mesozoic, Tertiary, Pleistocene, and Holocene) and for the two frequency bands $0.5-1.5 \mathrm{~Hz}$ and $2.0-6.0 \mathrm{~Hz}$. Two different averages are given: (1) the geometric average of all sites within the indicated surficial geologic unit, and (2) the value predicted by a regression relationship between shallow $S$-wave velocity and site amplification obtained by Harmsen (1996). For the second case, we use the arithmetic average of the $S$-wave velocity in each geologic unit. Because of variability within a rock type and possible topographic amplification at some sites, the average Mesozoic values are not all 1 . We therefore normalize the amplifications contoured on the maps and lists in tables 1, 2, and 3 so that the average Mesozoic values are 1. (The pre-normalization values for Mesozoic units are: $1.4(2.0-6.0 \mathrm{~Hz}$, average \#1), $1.9(2.0-6.0 \mathrm{~Hz}$, average \#2), 1.0 $(0.5-1.5 \mathrm{~Hz}$, average \#1), $1.3(0.5-1.5 \mathrm{~Hz}$, average \#2).)

Contouring of amplification values within the sedimentary basins is done using the inverse distance-weighted interpolation algorithm in the Arc/Info GIS software package. An interpolated value is a linearly weighted combination of a set of sample points. The weight is a function of inverse distance. This weighted distance average cannot be greater than the highest or less than the lowest input. Therefore, it cannot create highs or lows if these extremes have not already been sampled. In this process all the Pleistocene and Holocene data points are contoured together, without distinction. After contouring, the Mesozoic and Tertiary units are layed down as masks over the contours. The result is discontinuous contours at the contacts of the sedimentary basins with the Mesozoic 
and Tertiary outcrops, reflecting the discontinuous change in material properties and amplification factors. In addition, some of the contours are given hachures to clarify the down-gradient direction.

\section{ACCESSING DIGITAL FILES OF THE SITE-RESPONSE MAPS}

Traphics files of the site-response maps are a
color encapsulated-PostScript or HPGL2 files.
can be accessed from anonymous FTP server green
(136.177.48.5).
The following sequence of commands should be
on UNIX computers:
\% ftp greenwood.cr.usgs.gov
Name: your_name@your_system.your_domain
ftp $>$ dir
ftp $>$ get INDEX
ftp $>$ get README.FTP
ftp $>$ get LISTING.TXT
ftp $>$ cd pub
ftp $>$ dir
ftp $>$ cd open-file-reports
ftp $>$ dir
ftp $>$ cd ofr-96-0000
ftp $>$ dir
ftp $>$ binary
ftp $>$ get file_name
ftp $>$ quit

The text file INDEX contains a listing and short description of all publications in the /pub subdirectory, and README.FTP contains useful information on FTP file transfer. The text file LISTING.TXT is a long listing of files and the subdirectory structure below /pub. The site response map files are in subdirectory /pub/open-filereports/ofr-96-0000.

Questions regarding digital database dissemination should be directed to the database manager:

Eugene Ellis

U.S. Geological Survey

Box 25046, MS 902

Denver Federal Center

Denver, Colorado 80225

(303) 236-0953

gellis@ctr5.cr.usgs.gov

\section{DISCLAIMER}

The site-response maps have been approved for release and publication by the Director of the U.S. Geological
Survey (USGS). However, the USGS reserves the right to revise these maps pursuant to further analysis and review. Furthermore, these maps are released on condition that neither the USGS nor the United States Government may be held liable for any damages resulting from their authorized or unauthorized use.

\section{ACKNOWLEDGMENTS}

$\mathrm{M}$ any organizations and individuals contributed to the collection of the data using in this report. Strong motion records came from The California Strong Motion Instrumentation Program (CSMIP), the Civil Engineering Department of the University of Southern California (USC), the Los Angeles Department of Water and Power (LADWP), and the USGS. Aftershock data records were collected by Tom Bice, Paul Bodin, David Carver, Edward Cranswick, Arthur Frankel, Mark Meremonte, Jack Odum, Dee Overturf, Rob Williams, and David Worley of the USGS, Golden, Colo.; Chris Dietel, Gene Sembera, and Leif Wennerberg of the USGS, Menlo Park, Calif.; and Sue Hough of the USGS, Pasadena, Calif.

\section{REFERENCES}

Andrews, D.J., 1986, Objective determination of source parameters and similarity of earthquakes of different size, in Earthquake Source Mechanics: Geophysical Monograph 37, v. 6, p. 259-267.

Boore, D.M., Joyner, W.B., and Fumal, T.E., 1993, Estimation of response spectra and peak accelerations from western North American earthquakes--An interim report: U.S. Geological Survey Open-File Report 93-509, $72 \mathrm{p}$.

Boore, D.M., Joyner, W.B., and Fumal, T.E., 1994, Estimation of response spectra and peak accelerations from western North American earthquakes-An interim report, Part 2: U.S. Geological Survey Open-File Report 94-127, $40 \mathrm{p}$.

Borcherdt, R.D., 1970, Effects of local geology on ground motion near San Francisco Bay: Bulletin of the Seismological Society of America, v. 60, p. 29-61.

Borcherdt, R.D., 1994, Estimates of site-dependent response spectra for design (methodology and justification): Earthquake Spectra, v. 10, p. 617-654.

Campbell, K.W., 1976, A note on the distribution of earthquake damage in Long Beach, 1933: Bulletin of the Seismological Society of America, v. 66, p. 1001-1006. 
Glassmoyer, G., 1996, Digital recordings of aftershocks of the 17 January 1994 Northridge, California, earthquake: U.S. Geological Survey Open-File Report 960000 (in preparation).

Harmsen, S., 1996, Determination of site amplification in the Los Angeles urban area from inversion of strongmotion records: Bulletin of the Seismological Society of America (submitted).

Hartzell, S., Leeds, A., Frankel, A., and Michael, J., 1996, Site response for urban Los Angeles using aftershocks of the Northridge earthquake: Bulletin of the Seismological Society of America, v. 86, p. S168-S192.

Joyner, W., and Fumal, T.E., 1984, Use of measured Swave velocity for predicting geologic site effects on strong ground motion: Proceedings of the Eight World Conference on Earthquake Engineering, San Francisco, Calif., v. 2, p. 777-783.

Meremonte, M., Frankel, A., Cranswick, E., Carver, D., and Worley, D., 1996, Urban seismology-Northridge aftershocks recorded by multi-scale arrays of portable digital seismographs: Bulletin of the Seismological Society of America, v. 86, p. 1350-1363.

Porcella, R.L., Etheredge, E.C., Maley, R.P., and Acosta, A.V., 1994, Accelerograms recorded at USGS national strong-motion network stations during the $\mathrm{Ms}=6.6$ Northridge, California, eathquake of January 17, 1994: U.S. Geological Survey Open-File Report 94-141, $100 \mathrm{p}$.

Rogers, A.M., Tinsley, J.C., Hays, W.H., and King, K.W., 1979, Evaluation of the relation between near-surface geological units and ground response in the vicinity of Long Beach, California: Bulletin of the Seismological Society of America, v. 69, p.1603-1622.

Rogers, A.M., Covington, P.A., Park, R.B., Borcherdt, R.D., and Perkins, D.M., 1980, Nuclear event time histories and computed site transfer functions for locations in the Los Angeles region: U.S. Geological Survey Open-File Report 80-1173, 207 p.
Rogers, A.M., Borcherdt, R.D., Covington, P.A., and Perkins, D.M., 1984, A comparative ground response study near Los Angeles using recordings of Nevada nuclear tests and the 1971 San Fernando earthquake: Bulletin of the Seismological Society of America, v. 74, p. 1925-1949.

Rogers, A.M., Tinsley, J.C., and Borcherdt, R.D., 1985, Predicting relative ground response, in Evaluating earthquake hazards in the Los Angeles region-an earth-science perspective: U.S. Geological Survey Professional Paper 1360, p. 221-247.

Shakal, A., Huang, M., Darragh, R., Cao, T., Sherburne, R., Malhotra, P., Cramer, C., Sydnor, R., Graizer, V., Maldonado, G., Petersen, C., and Wampole, J., 1994, CSMIP strong-motion records from the Northridge, California earthquake of 17 January 1994: California Strong Motion Instrumentation Program Report 94-07, $308 \mathrm{p}$.

Shakal, A., Huang, M., Darragh, R., Brady, A., Trifunac, M., Lindvall, C., Wald, D., Heaton, T., and Mori, J., 1995, Recorded ground and structure motions, in Northridge earthquake of January 17, 1994, reconnaissance report: Earthquake Spectra, v. 11, Supplement C, p. 13-96.

Tinsley, J.C., and Fumal, T.E., 1985, Mapping Quaternary sedimentary deposits for areal variations in shaking response, in Evaluating earthquake hazards in the Los Angeles region-An earth-science perspective: U.S. Geological Survey Professional Paper 1360, p. 101-125.

Trifunac, M.D., Todorovska, M.I., and Ivanovic, S.S., 1994, A note on distribution of uncorrected peak ground accelerations during the Northridge, California, earthquake of 17 January 1994: Soil Dynamics and Earthquake Engineering, v. 13, p. 187-196.

Williams, R.A., Stephenson, W.J., Odum, J.K., and Worley, D.M., 1996, Shallow $P$ - and $S$-wave velocities at eleven aftershock recording stations of the Northridge earthquake, San Fernando valley, California: U.S. Geological Survey Open-File Report 96-261, 10 p. 
Table 1.-Aftershock station locations and amplification factors [Asterisk $\left({ }^{*}\right)$ indicates poor data quality]

\begin{tabular}{|c|c|c|c|c|}
\hline $\begin{array}{l}\text { Station } \\
\text { Code }\end{array}$ & Latitude & Longitude & $\begin{array}{c}\text { Amplification } \\
\text { Factor } \\
0.5 \text { to } 1.5 \mathrm{~Hz} \\
\end{array}$ & $\begin{array}{c}\text { Amplification } \\
\text { Factor } \\
2.0 \text { to } 6.0 \mathrm{~Hz} \\
\end{array}$ \\
\hline$\overline{\mathrm{ab} 1}$ & 34.2417 & -118.5244 & 3.18 & 2.19 \\
\hline ara & 34.2437 & -118.5698 & 2.06 & 1.64 \\
\hline $\arg$ & 34.1405 & -118.4320 & 2.75 & 2.20 \\
\hline ay 1 & 34.1533 & -118.4342 & 4.12 & 3.21 \\
\hline bem & 34.2088 & -118.5150 & 4.54 & 2.56 \\
\hline bh1 & 34.1888 & -118.5058 & 4.18 & 1.94 \\
\hline bhg & 34.0086 & -118.3615 & 3.58 & 1.79 \\
\hline bhp & 34.0064 & -118.3782 & 2.61 & 1.32 \\
\hline bla & 34.1465 & -118.4315 & 4.29 & 3.42 \\
\hline chs & 34.2247 & -118.5488 & 4.16 & 2.60 \\
\hline crs & 34.0338 & -118.3656 & 4.04 & 4.01 \\
\hline $\operatorname{cs} 1$ & 34.2423 & -118.5295 & 2.71 & 2.19 \\
\hline cse & 34.2248 & -118.5397 & 4.20 & 2.47 \\
\hline $\mathrm{drb}$ & 34.2365 & -118.5505 & 3.57 & 2.06 \\
\hline dwp & 34.0383 & -118.3706 & 2.65 & 1.73 \\
\hline er1 & 34.1488 & -118.5154 & ref. & ref. \\
\hline etw & 34.2172 & -118.5307 & 4.08 & 2.22 \\
\hline ews & 34.2127 & -118.5305 & 3.71 & 3.57 \\
\hline fp1 & 34.2592 & -118.5212 & 2.90 & 1.41 \\
\hline gld & 34.2422 & -118.5395 & 3.48 & 2.81 \\
\hline gar & 34.2677 & -118.5200 & 3.78 & 3.15 \\
\hline glo & 34.0358 & -118.3763 & 3.56 & 3.06 \\
\hline gre & 34.0370 & -118.3738 & 3.54 & 3.35 \\
\hline gth & 34.2717 & -118.4880 & 2.74 & 2.77 \\
\hline gts & 34.2708 & -118.4887 & 3.39 & 3.18 \\
\hline her & 34.0353 & -118.3747 & 3.48 & 4.66 \\
\hline hlt & 34.0366 & -118.3819 & 2.48 & 2.07 \\
\hline hol & 34.2208 & -118.4707 & 2.93 & 3.09 \\
\hline hws & 34.0893 & -118.4325 & 1.62 & 1.44 \\
\hline ia1 & 34.3374 & -118.5071 & 1.88 & 1.66 \\
\hline ia2 & 34.3359 & -118.5075 & 1.47 & 2.43 \\
\hline ia3 & 34.3349 & -118.5075 & 2.17 & 2.98 \\
\hline ia4 & 34.3350 & -118.5076 & $*$ & 2.24 \\
\hline ia 5 & 34.3360 & -118.5076 & $*$ & 1.96 \\
\hline jem & 34.3120 & -118.4960 & 2.64 & 1.85 \\
\hline jen & 34.1958 & -118.4630 & 3.26 & 2.46 \\
\hline jq1 & 34.2850 & -118.5240 & 3.09 & 2.01 \\
\hline jt1 & 34.1523 & -118.4338 & 4.59 & 2.50 \\
\hline ld 1 & 34.1527 & -118.4327 & 4.17 & 2.67 \\
\hline los & 34.1662 & -118.5157 & 5.06 & 1.01 \\
\hline lxa & 34.0293 & -118.4761 & 3.35 & 1.80 \\
\hline mam & 34.2535 & -118.5137 & 1.93 & 1.83 \\
\hline may & 34.1873 & -118.5487 & 3.94 & 2.36 \\
\hline mck & 34.1542 & -118.4363 & 6.20 & 5.17 \\
\hline me1 & 34.1922 & -118.5045 & 2.55 & 1.33 \\
\hline
\end{tabular}




\begin{tabular}{|c|c|c|c|c|}
\hline $\begin{array}{l}\text { Station } \\
\text { Code }\end{array}$ & Latitude & Longitude & $\begin{array}{c}\text { Amplification } \\
\text { Factor } \\
0.5 \text { to } 1.5 \mathrm{~Hz} \\
\end{array}$ & $\begin{array}{c}\text { Amplification } \\
\text { Factor } \\
2.0 \text { to } 6.0 \mathrm{~Hz} \\
\end{array}$ \\
\hline$\overline{\mathrm{mk} 1}$ & 34.2458 & -118.5293 & 3.48 & 2.43 \\
\hline $\mathrm{mk2}$ & 34.2448 & -118.5280 & 4.39 & 3.07 \\
\hline $\mathrm{mk} 3$ & 34.2448 & -118.5300 & 5.36 & 2.59 \\
\hline $\mathrm{mn} 1$ & 34.1927 & -118.5058 & 3.54 & 1.32 \\
\hline $\mathrm{ms} 1$ & 34.1917 & -118.5060 & 2.21 & 1.31 \\
\hline mue & 34.2428 & -118.6213 & 1.07 & 1.10 \\
\hline ncu & 34.2400 & -118.5655 & 2.61 & 1.59 \\
\hline npo & 34.2435 & -118.5347 & 3.64 & 1.86 \\
\hline nrs & 34.1614 & -118.5339 & 4.38 & 1.54 \\
\hline $\mathrm{nsl}$ & 34.1617 & -118.5303 & 2.97 & 1.28 \\
\hline omn & 34.2392 & -118.5912 & 3.01 & 2.56 \\
\hline pg1 & 34.2438 & -118.5233 & 3.52 & 2.91 \\
\hline pl1 & 34.2415 & -118.5228 & 2.76 & 2.03 \\
\hline pot & 34.2482 & -118.4998 & 2.51 & 2.08 \\
\hline pra & 34.0378 & -118.3777 & 3.13 & 3.08 \\
\hline $\mathrm{rgt}$ & 34.1602 & -118.5350 & 2.67 & 1.01 \\
\hline rom & 34.0372 & -118.3757 & 3.05 & 3.20 \\
\hline sc1 & 34.1890 & -118.5028 & 2.82 & 1.74 \\
\hline sch & 34.1510 & -118.4342 & 4.95 & 5.44 \\
\hline sef & 34.0173 & -118.3690 & 4.77 & 2.71 \\
\hline shs & 34.0385 & -118.3844 & 2.05 & 1.34 \\
\hline sk1 & 34.2101 & -118.5163 & 3.06 & 2.03 \\
\hline sla & 34.2315 & -118.5217 & 5.21 & 3.92 \\
\hline smc & 34.0122 & -118.4914 & 2.98 & 1.49 \\
\hline smi & 34.2487 & -118.5443 & 3.84 & 3.49 \\
\hline sms & 34.0403 & -118.4844 & 3.57 & 0.84 \\
\hline sor & 34.2102 & -118.5164 & 4.18 & 3.21 \\
\hline sry & 34.2247 & -118.5567 & 4.36 & 2.17 \\
\hline ssc & 34.0467 & -118.3556 & 1.98 & 0.88 \\
\hline syf & 34.3260 & -118.4440 & 1.94 & 1.83 \\
\hline tpc & 34.0840 & -118.5990 & 1.29 & 1.32 \\
\hline tre & 34.2095 & -118.5493 & 2.43 & 2.00 \\
\hline trm & 34.1597 & -118.5336 & 2.18 & 1.73 \\
\hline uk1 & 34.2567 & -118.5312 & 2.15 & 1.04 \\
\hline $\operatorname{van}$ & 34.2493 & -118.4777 & 2.06 & 1.80 \\
\hline wc1 & 34.2088 & -118.5173 & 2.94 & 2.25 \\
\hline wil & 34.0518 & -118.2628 & 1.99 & 1.11 \\
\hline woc & 34.2089 & -118.5174 & 6.51 & 2.49 \\
\hline wvn & 34.0543 & -118.4531 & 2.87 & 1.48 \\
\hline wvs & 34.0499 & -118.4485 & 1.99 & 0.92 \\
\hline yk1 & 34.1593 & -118.4323 & 3.06 & 1.30 \\
\hline yol & 34.2458 & -118.5400 & 3.27 & 1.95 \\
\hline
\end{tabular}


Table 2.-Main-shock station locations and amplification factors [Asterisk $\left(^{*}\right)$ indicates poor data quality]

\begin{tabular}{|c|c|c|c|c|}
\hline $\begin{array}{l}\text { Station } \\
\text { Code }\end{array}$ & Latitude & Longitude & $\begin{array}{c}\text { Amplification } \\
\text { Factor } \\
0.5 \text { to } 1.5 \mathrm{~Hz} \\
\end{array}$ & $\begin{array}{c}\text { Amplification } \\
\text { Factor } \\
2.0 \text { to } 6.0 \mathrm{~Hz} \\
\end{array}$ \\
\hline AHM & 33.8170 & -117.9510 & 2.03 & 1.50 \\
\hline ALF & 34.0700 & -118.1500 & 2.48 & 1.40 \\
\hline ALH & 34.0850 & -118.1490 & 2.66 & 1.36 \\
\hline ARA & 34.1272 & -118.0588 & 2.46 & 1.37 \\
\hline ARC & 34.1300 & -118.0360 & 2.06 & 1.94 \\
\hline $\mathrm{BAD}$ & 33.8890 & -117.9260 & 1.49 & 2.16 \\
\hline BAP & 33.8470 & -118.0180 & 2.11 & 2.39 \\
\hline $\mathrm{BCC}$ & 34.0580 & -118.4170 & 2.02 & 0.95 \\
\hline $\mathrm{BCF}$ & 34.1850 & -118.3080 & 2.18 & 1.75 \\
\hline $\mathrm{BCY}$ & 34.2040 & -118.3020 & 1.06 & 0.82 \\
\hline BGC & 33.9650 & -118.1580 & 2.81 & 1.65 \\
\hline $\mathrm{BHA}$ & 34.0090 & -118.3610 & 2.63 & 1.80 \\
\hline $\mathrm{BHO}$ & 34.0800 & -118.3900 & 1.44 & 0.77 \\
\hline BHR & 34.0700 & -118.4100 & 1.45 & 1.64 \\
\hline BHW & 34.0667 & -118.3893 & 1.94 & 1.69 \\
\hline BLD & 34.2330 & -117.6610 & 1.14 & 1.88 \\
\hline BPK & 34.1000 & -117.9740 & 1.29 & 0.92 \\
\hline BPM & 34.1870 & -118.3110 & 3.06 & 1.91 \\
\hline BRDG & 34.1400 & -118.1190 & 2.83 & 1.00 \\
\hline BREA & 33.9163 & -117.8963 & 1.77 & 2.07 \\
\hline BTS & 34.2860 & -118.2250 & 1.13 & 1.30 \\
\hline BWP & 34.1680 & -118.3320 & 3.76 & 3.20 \\
\hline CAS & 33.8120 & -118.2700 & 1.51 & 1.02 \\
\hline CBP & 34.0870 & -117.9150 & 1.79 & 1.05 \\
\hline CBS & 34.1510 & -118.6970 & 1.36 & 1.24 \\
\hline CCS & 34.0780 & -117.8710 & 1.99 & 1.19 \\
\hline $\mathrm{CDA}$ & 33.8360 & -118.2400 & 3.88 & 1.54 \\
\hline CND & 33.9160 & -117.8420 & 1.17 & 2.00 \\
\hline COM & 33.8990 & -118.1960 & 3.13 & 1.97 \\
\hline CPC & 34.2120 & -118.6010 & 2.91 & 2.42 \\
\hline CSB & 34.0670 & -118.1680 & 3.87 & 2.61 \\
\hline CTG & 34.1400 & -118.1300 & 2.54 & 2.03 \\
\hline CWH & 34.2590 & -118.5710 & 2.32 & $*$ \\
\hline DFL & 33.9130 & -117.8190 & 1.81 & 2.82 \\
\hline DOW & 33.9240 & -118.1670 & 3.95 & 1.78 \\
\hline DUA & 34.1500 & -117.9400 & 0.80 & 0.96 \\
\hline DWY & 33.9200 & -118.1370 & 3.29 & 2.17 \\
\hline $\mathrm{ECC}$ & 34.2590 & -118.3360 & 1.77 & 0.84 \\
\hline ECP & 34.1770 & -118.0960 & 2.11 & 1.61 \\
\hline EMC & 34.0930 & -118.0190 & 2.76 & 1.55 \\
\hline ERD & 34.1488 & -118.5153 & ref. & ref. \\
\hline FGA & 34.0555 & -118.2565 & 2.45 & 1.56 \\
\hline FGR & 34.0555 & -118.2568 & 3.09 & 2.03 \\
\hline FGU & 34.0500 & -118.2600 & 2.76 & 1.47 \\
\hline FRM & 34.0525 & -118.2577 & 2.89 & 2.08 \\
\hline
\end{tabular}




\begin{tabular}{|c|c|c|c|c|}
\hline $\begin{array}{l}\text { Station } \\
\text { Code }\end{array}$ & Latitude & Longitude & $\begin{array}{c}\text { Amplification } \\
\text { Factor } \\
0.5 \text { to } 1.5 \mathrm{~Hz} \\
\end{array}$ & $\begin{array}{c}\text { Amplification } \\
\text { Factor } \\
2.0 \text { to } 6.0 \mathrm{~Hz} \\
\end{array}$ \\
\hline$\overline{\text { FUL }}$ & 33.8800 & -117.8800 & 1.35 & 1.15 \\
\hline FVP & 33.7190 & -117.9370 & 2.77 & 1.54 \\
\hline FYP & 33.8690 & -117.7090 & 1.34 & 2.18 \\
\hline GDL & 34.1333 & -118.2472 & 5.13 & 2.28 \\
\hline GGS & 33.7900 & -118.0120 & 3.16 & 3.03 \\
\hline GLF & 34.2000 & -118.2310 & 1.25 & 2.88 \\
\hline GMC & 34.1370 & -117.8820 & 1.66 & 1.47 \\
\hline GPK & 34.1180 & -118.2990 & 2.59 & 1.64 \\
\hline GVR & 34.0500 & -118.1140 & 1.56 & 1.66 \\
\hline HACI & 33.9900 & -117.9425 & 1.51 & 1.12 \\
\hline HBW & 33.7272 & -118.0437 & 2.14 & 2.33 \\
\hline HIL & 34.0400 & -118.2600 & 2.84 & 0.86 \\
\hline HLC & 34.0880 & -118.3650 & 2.26 & 1.36 \\
\hline $\mathrm{HNB}$ & 33.6620 & -117.9970 & 1.68 & 1.16 \\
\hline IGU & 33.9050 & -118.2790 & 2.62 & 1.77 \\
\hline IRV & 33.6820 & -117.8420 & 2.66 & 2.88 \\
\hline JFP & 34.3120 & -118.4960 & $*$ & 0.84 \\
\hline JFPG & 34.3125 & -118.4977 & $*$ & 1.83 \\
\hline JPC & 34.2000 & -118.1700 & 1.26 & 1.09 \\
\hline KECK & 34.1400 & -118.1200 & 2.41 & 1.42 \\
\hline $\mathrm{LADF}$ & 34.2947 & -118.4788 & 2.27 & 0.66 \\
\hline LADN & 34.2997 & -118.4870 & $*$ & 1.75 \\
\hline LAJ & 34.0810 & -118.1880 & 1.77 & 1.12 \\
\hline LAPU & 34.0262 & -117.9182 & 1.31 & 1.11 \\
\hline LAS & 33.9290 & -118.2600 & 2.74 & 1.95 \\
\hline LAW & 33.8970 & -118.3460 & 2.12 & 0.94 \\
\hline LBC & 33.8810 & -118.1770 & 5.06 & 2.39 \\
\hline LBH & 33.7540 & -118.2000 & 3.42 & 1.27 \\
\hline LBL & 33.8400 & -118.1940 & 3.65 & 1.97 \\
\hline LBM & 33.9960 & -118.1620 & 2.99 & 2.12 \\
\hline LBO & 33.7680 & -118.1960 & 2.34 & 0.77 \\
\hline LBR & 33.7780 & -118.1330 & 2.17 & 0.74 \\
\hline LBS & 33.7830 & -118.1120 & 3.31 & 1.20 \\
\hline LBU & 33.7800 & -118.1100 & 3.02 & 1.57 \\
\hline LCA & 34.2380 & -118.2540 & 1.81 & 1.37 \\
\hline LCN & 34.0630 & -118.4180 & 2.51 & 1.55 \\
\hline LCS & 34.0620 & -118.4160 & 2.42 & 1.07 \\
\hline LCT & 34.0530 & -118.1710 & 2.30 & 3.12 \\
\hline LCY & 33.9450 & -118.3718 & 1.88 & 0.88 \\
\hline $\mathrm{LDH}$ & 34.0820 & -118.2880 & 1.86 & 2.00 \\
\hline LDS & 34.0880 & -118.2220 & 1.76 & 1.29 \\
\hline LF1 & 34.1150 & -118.2440 & 2.92 & 1.89 \\
\hline LF2 & 34.1130 & -118.1890 & 1.80 & 1.57 \\
\hline LF3 & 34.0420 & -118.5540 & 1.04 & 1.55 \\
\hline LF4 & 34.1460 & -118.4130 & 2.98 & 4.13 \\
\hline LF5 & 34.1270 & -118.4050 & 1.58 & 1.98 \\
\hline LF6 & 34.1320 & -118.4400 & 2.61 & 1.85 \\
\hline LHA & 33.9600 & -117.9500 & 2.10 & 1.17 \\
\hline LHO & 33.9210 & -117.9730 & 2.30 & 1.51 \\
\hline LNC & 33.9600 & -118.4200 & 1.47 & 0.85 \\
\hline
\end{tabular}




\begin{tabular}{|c|c|c|c|c|}
\hline $\begin{array}{l}\text { Station } \\
\text { Code }\end{array}$ & Latitude & Longitude & $\begin{array}{c}\text { Amplification } \\
\text { Factor } \\
0.5 \text { to } 1.5 \mathrm{~Hz} \\
\end{array}$ & $\begin{array}{c}\text { Amplification } \\
\text { Factor } \\
2.0 \text { to } 6.0 \mathrm{~Hz} \\
\end{array}$ \\
\hline$\overline{\mathrm{LND}}$ & 33.8960 & -118.3770 & 1.95 & 1.10 \\
\hline LNK & 34.1400 & -118.3600 & 1.24 & 1.09 \\
\hline LPS & 34.0430 & -118.2710 & 1.77 & 0.87 \\
\hline LSR & 33.9760 & -118.2890 & 2.95 & 2.03 \\
\hline LST & 34.0450 & -118.2980 & 2.16 & 1.19 \\
\hline LSU & 34.0670 & -118.2480 & 1.73 & 0.86 \\
\hline LTH & 34.0590 & -118.2460 & 2.07 & 1.10 \\
\hline LUH & 34.0620 & -118.1980 & 1.69 & 2.75 \\
\hline LURA & 34.1408 & -118.1205 & 2.85 & $*$ \\
\hline LVS & 34.0050 & -118.2790 & 2.13 & 1.92 \\
\hline LWD & 33.8460 & -118.0990 & 4.67 & 2.14 \\
\hline LWE & 34.1150 & -118.3800 & 0.63 & 0.56 \\
\hline LWS & 34.0900 & -118.4350 & 1.32 & 0.96 \\
\hline MBF & 33.8870 & -118.3890 & 2.19 & 1.30 \\
\hline MBS & 34.0010 & -118.4310 & 1.85 & 1.08 \\
\hline MCN & 34.0870 & -118.6930 & 0.61 & 0.69 \\
\hline MHI & 34.0600 & -118.2130 & 2.89 & 1.54 \\
\hline MSB & 34.0690 & -118.4420 & 1.12 & 0.80 \\
\hline MSM & 34.0860 & -118.4820 & 1.01 & 0.75 \\
\hline MTL & 33.9900 & -118.1140 & 1.77 & 1.43 \\
\hline MTW & 34.2240 & -118.0570 & 0.85 & 1.17 \\
\hline MUDD & 34.1410 & -118.1200 & 2.89 & 1.19 \\
\hline NBC & 33.6230 & -117.9310 & 2.59 & 1.93 \\
\hline NBI & 33.6340 & -117.9020 & 2.41 & 2.00 \\
\hline NHS & 34.1380 & -118.3590 & 2.12 & 1.14 \\
\hline NHW & 34.1940 & -118.4120 & 2.75 & 1.97 \\
\hline NIHB & 33.9160 & -118.0650 & 1.76 & 0.96 \\
\hline NIHN & 33.9170 & -118.0650 & 1.59 & 1.16 \\
\hline NOR & 34.0600 & -118.3167 & 2.36 & 1.57 \\
\hline NPB & 33.6180 & -117.8780 & 1.67 & 1.28 \\
\hline NRG & 34.2090 & -118.5170 & 3.41 & 2.18 \\
\hline NWKN & 33.9170 & -118.0670 & 1.54 & 1.37 \\
\hline NWKS & 33.9150 & -118.0670 & 2.42 & 1.29 \\
\hline OBG & 34.0370 & -118.1780 & 2.92 & 2.91 \\
\hline OCR & 33.9360 & -117.8840 & 1.03 & 2.24 \\
\hline OLI & 34.0472 & -118.2538 & 2.60 & 2.00 \\
\hline OLM & 34.0500 & -118.2700 & 2.72 & 2.06 \\
\hline OLV & 34.0472 & -118.2600 & 2.81 & 1.61 \\
\hline ORC & 34.1000 & -118.3400 & 1.21 & 1.31 \\
\hline ORG & 33.7800 & -117.8900 & 1.84 & 1.34 \\
\hline PAN & 34.2220 & -118.4420 & 3.46 & 3.50 \\
\hline PAS & 34.1390 & -118.1210 & 2.16 & 0.91 \\
\hline PASA & 34.1707 & -118.0795 & 2.06 & 1.50 \\
\hline PCD & 34.3340 & -118.3960 & 1.45 & 1.21 \\
\hline PCDA & 34.3340 & -118.3967 & $*$ & 3.08 \\
\hline PDQ & 33.9603 & -118.4322 & 2.62 & 0.91 \\
\hline PDR & 33.9603 & -118.4322 & 1.38 & 0.74 \\
\hline PEL & 34.0900 & -118.3400 & 2.96 & 1.74 \\
\hline PELB & 34.0903 & -118.3400 & 2.64 & 1.52 \\
\hline PHL & 34.0228 & -118.2830 & 2.22 & 1.20 \\
\hline
\end{tabular}




\begin{tabular}{|c|c|c|c|c|}
\hline $\begin{array}{l}\text { Station } \\
\text { Code }\end{array}$ & Latitude & Longitude & $\begin{array}{l}\text { Amplification } \\
\text { Factor } \\
0.5 \text { to } 1.5 \mathrm{~Hz} \\
\end{array}$ & $\begin{array}{c}\text { Amplification } \\
\text { Factor } \\
2.0 \text { to } 6.0 \mathrm{~Hz} \\
\end{array}$ \\
\hline$\overline{\mathrm{PKC}}$ & 34.2880 & -118.3750 & 3.39 & 1.98 \\
\hline PMC & 34.2510 & -118.4200 & 2.71 & 2.47 \\
\hline PMN & 34.0560 & -117.7480 & 0.93 & 0.79 \\
\hline PSL & 34.1490 & -118.1710 & 0.82 & 0.94 \\
\hline PSM & 34.1687 & -118.0780 & 1.87 & 2.45 \\
\hline PSW & 34.1360 & -118.1270 & 1.55 & 1.42 \\
\hline PUR & 34.0400 & -118.4450 & 5.42 & 2.09 \\
\hline PVC & 33.7460 & -118.3960 & 0.88 & 0.70 \\
\hline PVE & 33.8010 & -118.3842 & 1.71 & 0.91 \\
\hline PVR & 33.7720 & -118.3190 & 3.69 & 1.83 \\
\hline RHE & 33.7870 & -118.3560 & 1.44 & 1.72 \\
\hline RIN & 34.2810 & -118.4790 & $*$ & 1.75 \\
\hline ROB & 34.0755 & -118.3827 & 2.35 & 1.01 \\
\hline RPV & 33.7400 & -118.3340 & 1.52 & 0.90 \\
\hline RSE & 34.1760 & -118.3600 & 2.34 & 2.28 \\
\hline SBH & 33.7570 & -118.0840 & 2.62 & 2.45 \\
\hline SCC & 34.0970 & -118.4780 & 1.49 & 2.00 \\
\hline SCS1 & 34.3110 & -118.4900 & $*$ & 0.53 \\
\hline SCS2 & 34.3110 & -118.4897 & $*$ & 1.12 \\
\hline SCSE & 34.2953 & -118.4810 & $*$ & 1.40 \\
\hline SFS & 33.9440 & -118.0870 & 2.23 & 2.25 \\
\hline SFY & 34.2360 & -118.4390 & 2.55 & 1.31 \\
\hline SGS & 34.0920 & -118.0930 & 2.54 & 1.59 \\
\hline SIX & 34.0500 & -118.2500 & 2.18 & 0.89 \\
\hline SMC & 34.0050 & -118.4850 & 1.91 & 1.06 \\
\hline SMI & 34.2640 & -118.6660 & 2.78 & 2.00 \\
\hline SMO & 34.0110 & -118.4900 & 3.57 & 2.14 \\
\hline SNM & 34.1150 & -118.1300 & 1.98 & 1.05 \\
\hline SNT & 34.0972 & -118.3312 & 2.22 & 1.10 \\
\hline SNV & 34.2350 & -118.3670 & 1.53 & 1.11 \\
\hline SOK & 34.1540 & -118.4650 & 2.70 & 1.76 \\
\hline SPP & 33.7220 & -118.3090 & 1.27 & 1.64 \\
\hline SRW & 34.0280 & -118.2230 & 2.91 & 1.20 \\
\hline SSA & 34.2310 & -118.7130 & 1.24 & 0.82 \\
\hline SSC & 34.0470 & -118.3550 & 2.10 & 1.45 \\
\hline SST & 34.0972 & -118.3293 & 2.47 & 1.49 \\
\hline SUN & 34.2690 & -118.3030 & 2.32 & 1.08 \\
\hline SVG & 34.2210 & -118.4220 & 2.85 & 1.80 \\
\hline SXH & 34.0600 & -118.3000 & 2.78 & $*$ \\
\hline SYL & 34.3060 & -118.4370 & 2.30 & 1.74 \\
\hline SYLM & 34.3260 & -118.4440 & $*$ & 1.93 \\
\hline TMI & 33.7360 & -118.2690 & 2.29 & 1.86 \\
\hline TOP & 34.0840 & -118.5990 & 0.79 & 1.18 \\
\hline TOR & 33.8230 & -118.3560 & 1.87 & 1.04 \\
\hline TUS & 33.7278 & -117.8245 & 1.83 & 2.30 \\
\hline $\mathrm{UCA}$ & 34.0600 & -118.4200 & 1.53 & 0.88 \\
\hline $\mathrm{UCF}$ & 34.0600 & -118.4100 & 1.08 & 1.37 \\
\hline UCLA & 34.0680 & -118.4390 & 2.11 & 1.48 \\
\hline VCS & 34.0040 & -118.2300 & 2.43 & 1.11 \\
\hline VCSS & 34.0037 & -118.2303 & 2.22 & 1.30 \\
\hline
\end{tabular}




\begin{tabular}{|c|c|c|c|c|}
\hline $\begin{array}{l}\text { Station } \\
\text { Code }\end{array}$ & Latitude & Longitude & $\begin{array}{c}\text { Amplification } \\
\text { Factor } \\
0.5 \text { to } 1.5 \mathrm{~Hz} \\
\end{array}$ & $\begin{array}{c}\text { Amplification } \\
\text { Factor } \\
2.0 \text { to } 6.0 \mathrm{~Hz} \\
\end{array}$ \\
\hline VER & 34.0225 & -118.2925 & 1.21 & 0.86 \\
\hline VLA & 34.0630 & -118.4630 & 2.22 & 1.13 \\
\hline VLO & 33.7770 & -118.1150 & 1.74 & 1.37 \\
\hline VLOB & 33.7767 & -118.1147 & 1.79 & 1.18 \\
\hline VNA & 34.1600 & -118.4800 & 2.87 & 1.19 \\
\hline VNO & 34.2000 & -118.4600 & 2.70 & 0.86 \\
\hline VNT & 34.1522 & -118.4552 & 2.18 & 2.11 \\
\hline VNY & 34.2210 & -118.4710 & 3.35 & 1.89 \\
\hline VPS & 33.8210 & -117.8180 & 0.99 & 0.97 \\
\hline VRN & 34.0000 & -118.2000 & 3.05 & 1.92 \\
\hline VSP & 34.2490 & -118.4780 & 4.15 & 1.69 \\
\hline VWD & 34.0500 & -118.4490 & 2.23 & 1.25 \\
\hline VWDN & 34.0540 & -118.4530 & 2.38 & 1.53 \\
\hline VWDS & 34.0500 & -118.4480 & 2.66 & 1.80 \\
\hline WBV & 34.0625 & -118.3583 & 2.77 & 0.76 \\
\hline WCVA & 34.0642 & -117.9522 & 1.83 & 1.09 \\
\hline WHA & 34.0153 & -118.0287 & 1.21 & 0.84 \\
\hline WHB & 33.9760 & -118.0360 & 2.11 & 1.96 \\
\hline WIS & 34.0520 & -118.2630 & 1.52 & 0.84 \\
\hline WLB & 34.0617 & -118.3017 & 2.67 & 1.51 \\
\hline WLH & 34.0600 & -118.3000 & 2.41 & 1.24 \\
\hline WLR & 34.0600 & -118.2950 & 2.22 & 1.18 \\
\hline WLS & 34.0600 & -118.2800 & 2.32 & 0.83 \\
\hline WND & 34.0200 & -118.0530 & 1.53 & 1.83 \\
\hline WNDU & 34.0250 & -118.0530 & 1.57 & 1.24 \\
\hline WPB & 34.0600 & -118.2500 & 2.23 & 1.11 \\
\hline WTW & 34.3600 & -117.6300 & 0.77 & 1.24 \\
\hline WWS & 34.3690 & -117.6580 & 1.32 & 2.00 \\
\hline
\end{tabular}


Table 3.--Average amplification

\begin{tabular}{|c|c|c|c|c|c|c|c|}
\hline \multicolumn{6}{|c|}{\begin{tabular}{c|c}
\multicolumn{2}{c}{ Average amplification factors* } \\
Short Period & Intermediate Period \\
$(2.0$ to $6.0 \mathrm{~Hz})$ & $(0.5$ to $1.5 \mathrm{~Hz})$
\end{tabular}} & \multirow{2}{*}{$\begin{array}{l}\text { Average } \\
\text { S-wave } \\
\text { velocity } \\
(\mathrm{m} / \mathrm{s})\end{array}$} & \multirow[t]{2}{*}{ Surficial geologic unit } \\
\hline (1) & SD(1) & (2) & (1) & SD(1) & $(2)$ & & \\
\hline 1.0 & 0.09 & 1.0 & 1.0 & 0.13 & 1.0 & 710 & $\begin{array}{l}\text { Mesozoic and pre-Mesozoic } \\
\text { crystalline and metasedimentary } \\
\text { rocks. }\end{array}$ \\
\hline 1.8 & 0.12 & 1.2 & 1.8 & 0.17 & 1.5 & 407 & $\begin{array}{l}\text { Tertiary and pre-Tertiary } \\
\text { sedimentary rocks. }\end{array}$ \\
\hline$\overline{1.6}$ & 0.12 & 1.3 & 2.2 & 0.10 & 1.5 & 368 & Pleistocene alluvium \\
\hline$\overline{1.9}$ & 0.11 & 1.3 & 2.2 & 0.16 & 1.7 & 321 & Holocene alluvium \\
\hline
\end{tabular}

(1) Average amplification for all sites within the indicated surficial geologic unit.

(2) Amplification from regression relationship between $S$-wave velocity and site response using average $S$-wave velocities for the indicated geologic unit.

$\mathrm{SD}(1)$ Standard deviation for average (1).

*Normalized to 1.0 for Mesozoic units. (pre-normalization values for Mesozoic units: 1.4, short period (1); 1.9, short period (2); 1.0, intermediate period (1); 1.3, intermediate period (2)) 